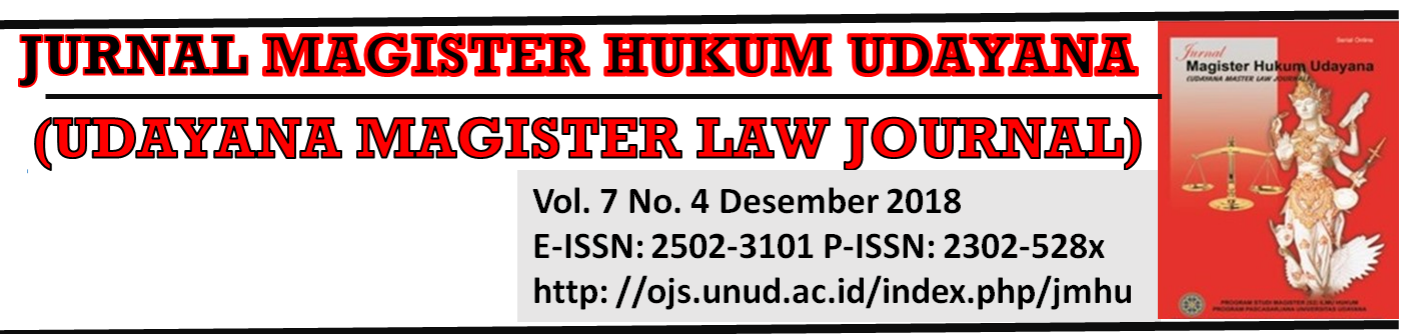

\title{
The Issue of Authority Between The National Police Republic of Indonesia and National Narcotics Agency in Handling The Case of Narcotics
}

\author{
Isya Nalapraja ${ }^{1}$ \\ ${ }^{1}$ Regional Office of the Ministry of Law and Human Rights of the Province of Bali, \\ e-mail: isyanalapraja@yahoo.co.id
}

\begin{tabular}{l}
\hline info article \\
\hline Received: $5^{\text {th }}$ October 2018 \\
Accepted: $4^{\text {th }}$ December 2018 \\
Published: $31^{\text {th }}$ December 2018 \\
\\
Keywords: \\
Dispute of Authority; Policy \\
With National Narcotics \\
Agency; Narcotics. \\
Corresponding Author: \\
Isya Nalapraja, E-mail: \\
isyanalapraja@yahoo.co.id \\
DOI: \\
10.24843/JMHU.2018.v07.i04. \\
p01
\end{tabular}

\begin{abstract}
Narcotics eradication is carried out by the National Narcotics Agency based on Law Number 35 of 2009 concerning Narcotics concerning investigations, and narcotics precursor accompanied by wiretapping. In addition to the National Narcotics Agency in Law Number 2 of 2002 concerning the Police that Police Investigators and Civil Servant Investigators have the same authority in combating narcotics. This will lead to a mechanism duet against law enforcement in the framework of eradicating narcotics. This study uses normative legal research methods that depart from the existence of conflicting norms between the authority of the Police and the National Narcotics Agency. Due to the occurrence of authority disputes between the National Narcotics Agency and the Police Force, law enforcement has been ineffective because of the poor coordination of the two institutions and Agency, resulting in competing for authority and causing abuse of authority.
\end{abstract}

\section{Introduction}

Narcotic is a substance or drug which is very useful and needed for the treatment of certain disease. However, if misused or used not according to treatment standard it can lead to very detrimental consequences for individuals or society in particular young generations. It will be more harmful if accompanied with the abuse and illicit drug trafficking which can lead to greater danger for life and the values of nation's culture which ultimately will be able to weaken the national endurance.

Besides that Indonesia is very vulnerable to illicit drug trafficking, from consumption aspect, in this case, narcotics abuse in fact indeed in quality and quantity tends to increase, even it can be predicted that narcotics abuse crime in the future will increase parallel with the development of society. It is marked with the emergence of crime modus operandi by utilizing technology in the field of transportation, communication and information as a means of committing a crime.

Awareness that narcotics abuse is similar to other community diseases such as gambling, prostitution, theft, and homicide which is difficult to eradicate or it can be said that it cannot be eliminated at all, so what can be done realistically is only by finding the way to suppress and control down to minimize as possible. 
Government and society feel the needs to eradicate this narcotics issue, related to the issue of protection then the Police have duty and authority to solve this narcotics issue. The Police, in this case, should be able to put an end and even annihilate all forms of narcotics and illicit drug trafficking as well as should be able to enforce the law so that people will no longer feel worried to this hazard. Through the Law No. 35 year 2009 regarding Narcotics, not only the Police is authorized to carry out the effort of law enforcement as well as the war against narcotics but also National Narcotics Agency which currently as the main commander in handling narcotics issue in Indonesia.

A significant emphasis of the Law No. 35 year 2009 is the authority of BNN and investigation, in which this law gives a big portion for BNN's investigators. The authority of BNN's investigation according to the Law No. 35 year 2009 is almost like Corruption Eradication Commission (KPK), the difference is only that BNN is not directly prosecuting, but it is still through public prosecutor from prosecutor's office.

According to the Law No. 35 year 2009, in case of conducting narcotics eradication, $\mathrm{BNN}$ is given authority to carry out probe and investigation against narcotics abuse, narcotics distribution and narcotics precursor accompanied with the authority given to the BNN's probers and investigators such as arresting for $3 \times 24$ hours and can be extended to $3 \times 24$ hours plus tapping. However, besides the BNN's investigators, in the law also being set the authority of other investigators namely Police's investigators, and civil servants' investigators (PPNS). Therefore the effectiveness of enactment of the Law No. 35 year 2009 regarding Narcotics is very dependent on directly related agencies namely investigators of the Police force, the PPNS and the BNN.

The portion of BNN's authority which is too big such as in arresting and searching according to the Law No. 35 year 2009, in fact, is not equal to the authority being given to investigators of the Police and PPNS. This difference is potential to create problem institutionally, as well as a sense of legal equality for the suspect who is being investigated by BNN and by the Police force. The presence of BNN institution certainly will be a dual mechanism to narcotics law enforcement along with Police institution, even in addition there is one more investigator's body namely PPNS, in which BNN is given the authority to conduct investigation against narcotics crime, other than that it can also be performed by police's investigators.

Based on the exposure of explanation above, so it can put forward the problem which will be studied in this writing that is how about the dispute of authority between the Police force and BNN in narcotics eradication and how is the consequence of this authority dispute in the implementation of law enforcement. This writing aims to find out whether there is a dispute of authority between the Police and BNN in narcotics eradication as well as to find out the consequence of such authority dispute in the process of law enforcement on narcotics eradication.

This research is genuine scientific work which has never been studied before. Whereas scientific work related to this author's scientific work regarding authority issue between the National Police Republic of Indonesia and National Narcotics Agency in handling narcotics case namely scientific work by Ida Bagus Putu Swadharma Diputra in the year 2012 with title of "The Policy of Rehabilitation towards Narcotics Abuse in the Law No. 35 year 2009 regarding Narcotics" which its problem formulation was how about the formulation of rehabilitation policy in the Law Number 35 year 2009 
regarding Narcotics. ${ }^{1}$ Other scientific work which is related namely by A.A. Istri Mas Candra Dewi year 2012 with title of "Legal Protection towards the Victims of Narcotics Abuse with the Enactment of the Law Number 35 year 2009 regarding Narcotics" which its problem formulation was how about the monitoring of rehabilitation decision for victims of narcotics abuse with the enactment of the Law Number 35 year 2009 regarding Narcotics. ${ }^{2}$ It is clearly visible the difference between those scientific works and the author's scientific work. As for the advantage of this scientific work compared to others is that it examines more deeply regarding authority issue between the National Police Republic of Indonesia and National Narcotics Agency in handling narcotics case.

\section{Research Method}

This study uses a normative legal research method. Starting from the presence of norm conflict between the Article 15 paragraph (1) letter c, the Law Number 2 year 2002 regarding the National Police Republic of Indonesia namely "In order to carry out assignments as referred to in Article 13 and 14, the National Police Republic of Indonesia, in general, has an authority to prevent and overcome the growth of community disease". Explanation of the Article is "what it is meant by community disease among others are begging and bummer, prostitution, gambling, drugs or narcotics abuse, drunk, human trafficking, sucking/money lender practice, and illegal levies", with Article 64 paragraph (1) the Law Number 35 year 2009 regarding Narcotics namely "In order to preventing and eradication of narcotics abuse and illicit narcotics trafficking and Narcotics precursor, with this Law it created National Narcotics Agency, which further shortened to BNN. The approach being used in this research is the regulatory approach, case approach, and Analytical and Conceptual approach. By using primary legal material, secondary legal material and tertiary legal material, which is collected using the snowball method, which further being analyzed using description, argumentation and systematization techniques.

\section{Result and Discussion}

\subsection{Authority Dispute between Police Force and BNN}

The term of wewenang or kewenangan is parallel with authority in English and bevoegdheid in Dutch. Authority is a legal power, rights to governor take action; rights or power of public officers to comply with legal rules in the scope to carry out public obligation. The meaning of authority based on Black's Law Dictionary is the right or permission to act legally on another's behalf, especially the power of one person to affect another's legal relations by an act done in accordance with the other's

1 Diputra, I. B. P. S. (2013). Kebijakan Rehabilitasi Terhadap Penyalah Guna Narkotika Pada Undang-Undang Nomor 35 Tahun 2009 Tentang Narkotika.Jurnal Magister Hukum $\begin{array}{lllll}\text { Udayana } & \text { (Udayana Master }\end{array}$ https://doi.org/10.24843/JMHU.2013.v02.i01.p10

2 Dewi, C., \& Mas, A. I. (2012). Perlindungan Hukum terhadap Korban Penyalahguna-an Narkotika dengan Berlakunya Undang-undang Nomor 35 Tahun 2009 Tentang $\begin{array}{llll}\text { Narkotika.Jurnal Magister Hukum } & \text { Udayana. }\end{array}$ https://doi.org/10.24843/JMHU.2012.v01.i01.p01 
manifestations of assent. ${ }^{3}$ The term Bevoegdheid is being used in the concept of private law and public law, meanwhile, authority is always used in the concept of public law. Theoretically, the authority originated from the legislation is acquired in three ways, namely attribution, delegation, and mandate. 4

For this reason later what is required to be discussed is regarding the sources of the authority itself. In line with the main pillar of the State of Law which is the legality principle (legaliteits beginselen or wetmatigheid van bestuur), based on this principle that government authority is originated from legislation. In the legal administration literature there are two ways to acquire the government authority namely attribution and delegation; sometimes also, mandate, placed as a separate method to acquire the authority. Attribution authority is an original authority originated from the Constitution of Republic of Indonesia year 1945, delegation authority is an authority given through the Law which is based on the existence of authority by attribution, and mandate is an authority carried out by other agency on behalf of its name. ${ }^{5}$

So in its every action, the government is supposed to be very concerned about legality principle as contained in Article 1 paragraph (3) of the Constitution of Republic of Indonesia year 1945 which states that Indonesia is a nation of law which means that every action by the government has its legal basis for implementation. Otherwise, this government's action in conducting its authority is illegal and null and void. In order for the government while running its administration and acting based on the authority embedded within it, then the government must be carefully giving attention to the theory of authority so that in the future the action by the government is not considered as abusing its authority.

In relation to what has been described before, Police force in this case as State institution which has been given its authority by attribution in the Constitution of Republic of Indonesia year 1945 and the Law No. 2 year 2002 regarding the National Police Republic of Indonesia is a legal protection and legitimate basis to carry out its authority as has been regulated in legislation. In the Constitution of Republic of Indonesia year 1945 Article 30 paragraph (4) states that the National Police Republic of Indonesia as state tool which maintains public security and order which has a duty to protect, guard and serve people, as well as enforcing the law. Later it was reaffirmed in the Law No. 2 year 2002 regarding the National Police Republic of Indonesia Article 15 paragraph (1) and (2).

Related to this narcotics issue, authority possessed by the Police in relation to law enforcement, regarding narcotics which has been prohibited of its distribution and consumption in Indonesia, it is natural that the Police which has the authority to enforce the law, however by the promulgation of the Law No. 35 year 2009 regarding Narcotics, it was mandating the creation of BNN which is more operational and has

3 Garner, B. A.. (1999). Black's Law Dictionary. Ninth Edition. USA: West Law Publishing. p. 592

4 Juwahyudhi, I. W. (2013). Wewenang Kepolisian Mengadakan Tindakan Lain dalam Memberikan Perlindungan Hukum terhadap Anak Menurut Undang-undang No. 11 Tahun 2012 Tentang Sistem Peradilan Pidana Anak. Jurnal Magister Hukum Udayana (Udayana Master Law Journal), 2(3). https:// doi.org/10.24843/JMHU.2013.v02.i03.p03.

5 Artaya, A. Kewenangan Pemerintah Kabupaten Badung dalam Pengendalian Perizinan Pembangunan Sarana Akomodasi Pariwisata. Jurnal Magister Hukum Udayana (Udayana Master Law Journal), 5(3), 543-558. https://doi.org/10.24843/JMHU.2016.v05.i03.p10 
authority for investigation of narcotics abuse and narcotics precursor. This investigation authority until this time was the authority of the Police department. The presence of this authority besides strengthening the institution of BNN, all at once also raising concern for unhealthy competition between BNN's investigators and Police's investigators, at least in the initial stage of its implementation. This concern is reasonable in light of narcotics crime and narcotics precursor has quite strategic values.

The existence of authority by BNN's investigators which is so great in the investigation, as regulated in Article 75 the Law No. 35 year 2009, then BNN's authority tends to deviate from KUHAP principles as well as universal principles that have been in effect all this time in criminal law. As a new institution, BNN is a special agency which handles narcotics issue, in addition, the authority contained in the Law No. 35 year 2009 regarding Narcotics, the existing regulations must adjust and synchronize to this law related to this narcotics issue.

To avoid the overlap of authority related to equal authority possessed by state institutions, so the role of coordination is urgently required in order to achieve success in law enforcement. According to Sukardi, weak coordination between law enforcement agencies can cause overlap of authority and policy of each party. This condition is vulnerable to create a conflict of interest between law enforcement agencies.

\subsection{Consequences on Law Enforcement}

Law enforcement in a broad sense includes activities to carry out and implement the law as well as taking legal action against any violation or legal deviation committed by a legal subject, either through justice procedure or through arbitration procedure and other dispute settlement mechanism. Moreover, in the broader sense, the activity of law enforcement also covering every activity that intended to be law as normative method tools which regulate and binds all legal subjects in every aspect of public and state life is really obeyed and really to be done properly. In a narrow sense, this law enforcement involves the activity of taking action against any violation or deviation to the laws and regulations, especially in the narrower sense through criminal justice process which involving the role of police's officers, prosecutors, advocates or lawyers, and judicial bodies.

Therefore, in the narrow sense, the main actors whose roles are very prominent in the process of law enforcement is the police, prosecutors, lawyers and judges. These law enforcers can be seen first as people or human element with quality, qualification, and their work cultures, respectively. In such sense, the issue of law enforcement depends on the actors, perpetrators, officers or law enforcement apparatus themselves. Secondly, law enforcers can also be seen as institutions, bodies or organizations with bureaucratic qualities of their own. In connection with that, we can see law enforcement from an institutional perspective which in reality has not been institutionalized rationally and impersonally. However, both perspectives need to be understood comprehensively by observing also its relationship one another as well as its connection with various factors and elements related to the law itself as a rational system.

Basically the success of law enforcers in law enforcement including legal structure, legal substance and legal culture as quoted from Lawrence M. Friedman that is "A 
legal system in actual operation is a complex organism in which structure, substance and culture interact". ${ }^{6}$ Legal structure is related to the legal institution, the legal substance is related to legal content or legal norm and legal culture is the values exist in society in connection with the law and legal system.

In conducting law enforcement related to narcotics abuse often occurred overlap and struggle in performing the action of law enforcement against narcotics case, this is due to equal authority on these two institutions that are BNN and Police force. The Police which in the Constitution of Republic of Indonesia year 1945 have an authority to enforce the law and maintain public order, in general, is a law enforcement body for state security, so that regarding narcotics abuse is an issue for state security since it can damage public order because the presence of narcotics can cause an increase of other criminal activities. This is due to in order to fulfill the need for narcotics, the addicted individual who does not have an established economy often justifies any means in order to get money to buy narcotics for their consumption because if they do not consume it, they will be in the state of doping up. Later on, with the presence of the Law No. 35 year 2009, the authority of the Police also being granted to BNN to perform eradication of every form of narcotics abuse.

Law enforcement and law utilization are two different things. People can enforce the law to give justice, but people also can enforce the law to be used for achieving an objective or other interest. Basically, law enforcement manifests the values or principles which containing justice and truth, law enforcement is not only the duty for law enforcers commonly known conventionally but the duty of everybody.

In narcotics case, BNN and Police have equal authority related to the prosecution of each narcotics case, it is certainly will cause overlap on each implementation of this authority. According to the theory which refers to the principle of lex specialis derogate lex generalis, so with the implementation of the Law No. 35 year 2009 regarding Narcotics which assigns BNN as the body which most specifically to eradicate narcotics abuse so that $\mathrm{BNN}$ is the most authorized to carry out the order of this law as law enforcers. "BNN and the Police as law enforcers are supposed to really understand to fulfill legal spirit which underlying legal regulations to be enforced, because of Indonesia as the state of law which means that all state administration is based on law, in which law regulations is applicable towards all state's bodies or tools"7.

Law enforcers also are demanded to pay attention to the orderly principle of state administration. One of the characteristics of good law enforcement is reflected from administration order in the process of law enforcement and the integration and harmony between law enforcers particularly in the criminal justice system which known as Integrated Criminal Justice System. Integration between law enforcers cannot be misunderstood so that only put forward cooperation between law enforcers which can result in bias leading to disorderly of administration or even law violation. Cooperation between law enforcement officers is intended to expedite effort of law enforcement in accordance with fast, simple and low-cost principles as well as free, fair

6 Friedman, L. M. (1975). The legal system: A social science perspective. New York: Russell Sage Foundation. p. 16.

7 Septika, L. P. S. (2016). Tanggung Jawab Negara Dalam Penyelesaian Pelanggaran Hak Asasi Manusia. Jurnal Magister Hukum Udayana (Udayana Master Law Journal), 5(4), 661-676. https://doi.org/10.24843/JMHU.2016.v05.i04.p03 
and impartial in case settlement. In other words, integration is intended to create effectivity and efficiency which is another characteristic of good governance by always paying attention to the law and administration order.

Reformation of law as one of the reformation agendas demanded by people is not only wishing for improvement on law materials or regulations but also the improvement of performance by law enforcers. The sensitivity of law enforcers must be clearly reflected in behavioral pattern and professionalism and the performance of law enforcers which is a reflection from the Professionalism Principle. Every law enforcer is demanded to keep improving his self-ability both technically and academically because those are logical consequences from the rapid development of modern technology which also affect the psychological development of modern society. Law enforcer is demanded to always willing to follow the development of science according to technology advancement without abandoning social-cultural of their nation. Professional ethics of law enforcers must always be oriented to the general interest of its society.

\section{Conclusion}

Whereas the cause of authority dispute between the Police force and BNN was started with equal authority possessed by both state institutions in connection to the prevention of narcotics issue namely in the process of probing, investigation as well as forced effort given by legislation.

Whereas with the occurrence of authority dispute between BNN and Police force leads to law enforcement not running effectively due to poor coordination on both institutions so that there is a mutual struggle for authority and causing an abuse of authority.

\section{Bibliography \\ Book}

Friedman, L. M. (1975). The legal system: A social science perspective. New York: Russell Sage Foundation.

Garner, B. A.. (1999). Black's Law Dictionary. Ninth Edition. USA: West Law Publishing.

\section{Journal}

Artaya, A. (2016). Kewenangan Pemerintah Kabupaten Badung dalam Pengendalian Perizinan Pembangunan Sarana Akomodasi Pariwisata. Jurnal Magister Hukum Udayana (Udayana Master Law Journal), 5(3), 543-558. https:// doi.org/10.24843/JMHU.2016.v05.i03.p10

Diputra, I. B. P. S. (2013). Kebijakan Rehabilitasi Terhadap Penyalah Guna Narkotika Pada Undang-Undang Nomor 35 Tahun 2009 Tentang Narkotika.Jurnal Magister Hukum Udayana (Udayana Master Law Journal). 2(1). https://doi.org/10.24843/JMHU.2013.v02.i01.p10

Dewi, C., \& Mas, A. I. (2012). Perlindungan Hukum terhadap Korban Penyalahguna-an Narkotika dengan Berlakunya Undang-undang Nomor 35 Tahun 2009 Tentang 
$\begin{array}{llll}\text { Narkotika.Jurnal Magister Hukum } & \text { Udayana. }\end{array}$ https://doi.org/10.24843/JMHU.2012.v01.i01.p01

Juwahyudhi, I. W. (2013). Wewenang Kepolisian Mengadakan Tindakan Lain dalam Memberikan Perlindungan Hukum terhadap Anak Menurut Undang-undang No. 11 Tahun 2012 Tentang Sistem Peradilan Pidana Anak. Jurnal Magister Hukum Udayana (Udayana Master Law Journal), 2(3). https://doi.org/10.24843/JMHU.2013.v02.i03.p03

Septika, L. P. S. (2016). Tanggung Jawab Negara Dalam Penyelesaian Pelanggaran Hak Asasi Manusia. Jurnal Magister Hukum Udayana (Udayana Master Law Journal), 5(4), 661-676. https://doi.org/10.24843/JMHU.2016.v05.i04.p03

\section{Legal Document}

Undang Undang Dasar Negara Republik Indonesia Tahun 1945

Undang Undang Nomor 2 Tahun 2002 Tentang Kepolisian Negara Republik Indonesia (Lembaran Negara RI Nomor 2 - Tambahan Lembaran Negara RI Nomor 4168)

Undang Undang Nomor 35 Tahun 2009 Tentang Narkotika (Lembaran Negara RI Nomor 143 - Tambahan Lembaran Negara RI Nomor 5062) 